\section{Australian Journal of \\ Crop Science}

AJCS 14(12):1876-1882 (2020)

doi: 10.21475/ajcs.20.14.12.2631
ISSN:1835-2707

\title{
Effect of nicosulfuron on chlorophyll content of marandu-grass cultivated in crop- forest-livestock integration systems
}

\author{
Evander Alves Ferreira ${ }^{1 *}$, Marcia Vitória Santos ${ }^{2}$, Leandro Diego da Silva ${ }^{2}$, Priscila Júnia Rodrigues da \\ Cruz $^{3}$, Raul Ribeiro Silveira ${ }^{2}$, Igor Costa de Freitas ${ }^{1}$, Leidivan Almeida Frazão ${ }^{1}$, Alcinei Místico de Azevedo ${ }^{1}$, \\ Gustavo Antônio Mendes Pereira ${ }^{4}$, Thiago Gomes dos Santos Braz ${ }^{1}$
}

\author{
${ }^{1}$ Instituto de Ciências Agrárias, Universidade Federal de Minas Gerais, Campus Regional de Montes Claros (ICA), Av. \\ Universitária 1000, Montes Claros, MG, CEP: 39400-090, Brazil \\ ${ }^{2}$ Universidade Federal dos Vales do Jequitinhonha e Mucuri, Campus JK, Rod. MGT 367 km 583, Diamantina, MG, \\ CEP: 39100-000, Brazil \\ ${ }^{3}$ Universidade Federal de Lavras, Campus da UFLA, Lavras, MG, CEP: 37.200-000, Brazil \\ ${ }^{4}$ Universidade Federal de Vicosa, Campus da UFV, Vicosa, MG, CEP: 36.570-000, Brazil
}

*Corresponding author: evanderalves@gmail.com

\begin{abstract}
The aim of this work was to study the effect of sub-doses of herbicide nicosulfuron on the levels of chlorophyll and growth of marandu-grass in an forest-livestock integration system. The treatments consisted of eucalyptus consortium with sorghum (BRS 655 hybrid) and forage Urochloa brizantha cv. Marandu (marandu-grass) at $12 \times 2$ and $12 \times 3 \mathrm{~m}$ spacings in agroforestry systems, in addition to sorghum + marandu-grass and marandu-grass in monoculture. The doses of nicosulfuron applied at the marandu-grass were 0,15 and $30 \mathrm{~g} \mathrm{ha}^{-1}$. At 30 and 120 days after the application of nicosulfuron, chlorophyll a and chlorophyll b were measured usinf a portable chlorophyll meter, with six measurements per plant. Afterwards, the total chlorophyll content and chlorophyll a/b were calculated. We also measured the mass of the total dry matter of marandu-grass and growth rate of the culture. Marandugrass plants cultivated in monoculture showed higher quantities of chlorophyll and the highest growth rates. The levels of chlorophyll $\mathrm{a}, \mathrm{b}$ and chlorophyll $\mathrm{a} / \mathrm{b}$ and the growth rate of marandu grass were similar between systems integrated with eucalyptus (12x2 and $12 \times 3 \mathrm{~m})$. The increase of herbicide dose negatively influenced on chlorophyll content in marandu-grass in all treatments evaluated. The use of nicosulfuron in doses of 25 and $50 \mathrm{~g} \mathrm{~L}^{-1}$ reduced the growth rate of marandu grass only when grown in monoculture.
\end{abstract}

Keywords: chlorophyll a, growth rate, competition, Urochloa brizantha.

Abbreviations: DAA_days after application; DAT_days after application of treatments; DBS_days before sowing; T_treatment.

Introduction

The forestry, livestock and agriculture activities are based on the equilibrium of the exploration of natural resources by the three main biotic components of the system: tree, pasture and culture. Therefore, it makes possible the simultaneous production of the arboreal, forage and agricultural components, when the interactions are balanced from the establishment to the final harvest of the products. However, it is common to assess difficulties in the balanced management of the components under rural property conditions, which are often caused by the establishment of spacing and tree arrangements that are inadequate for the development of forage species (Santos et al., 2018).

Tree, crop and pasture are in a state of competition for preferential access to available natural resources, such as radiation, water and nutrients. Frequently, the radiation factor is the most important and determinant element of the growth potential of forage species that grow under trees in integration systems (Oliveira et al., 2014).
From a certain stage of development, the presence of the tree and in the cases of agroforestry systems the presence of the crop can impose restrictive conditions of luminosity for the growth of the forage species established between the lines of forestry-livestock and crop-forestry-livestock systems (Valladares et al., 2008).

The study of luminosity and its relation with photosynthesis is fundamental for the evaluation of the potential of the species for cultivation in polyculture systems, since the availability of light is one of the critical factors for its development. The growth and adaptation of the plant to different environments are related to its reproductive efficiency, which is associatedwith foliar chlorophyll content, among other factors (Gómez et al., 2008). The levels of chlorophyll and carotenoids in the leaves are used to estimate the photosynthetic potential of the plants, by their direct connection with the absorption and transfer of light energy and the growth and adaptation to different environments. A plant with a high content of chlorophyll is 
able to reach higher photosynthetic rates for its potential value of capturing "quanta" per unit of time (Chappelle et al., 1992). Forages used in the integration system should have some degree of tolerance to shading. The tolerance of various forage species to shading depends on dry matter production under shaded conditions, planting density, tree spacing, soil and climate characteristics and vegetation management (Oliveira et al., 2013). Nicosulfuron is a selective herbicide that kills weeds and does not cause drastic deleterious effects to the main crop being cultivated (De Lafontaine et al., 2014; Wang et al., 2019). This herbicide belongs to the group of sulfonylureas, which act by inhibiting the enzyme acetolactate synthase - ALS inhibiting the synthesis of branched chain amino acids such as leucine, isoleucine and valine, disrupting protein synthesis. In turn, it interferes with the synthesis of DNA and cell growth. After absorption, these kinds of herbicides are quickly translocated either via the apoplast (exclusively through the cell walls) and symplast (moves from one cell to the other through plasmodesma) to areas of active growth (meristems and apices), where the growth is inhibited in susceptible plants (Concenço et al., 2007) such as genus Urochloa. In this way, the plants end up dying for the inability to produce essential amino acids.

Therefore, the objective of this work was to study the effect of subdoses of the herbicide nicosulfuron on the levels of chlorophyll and growth of marandu-grass in the forestlivestock integration system.

\section{Results and discussion}

\section{Chlorophyll b content in marandu-grass plants}

In the initial evaluation phase (30 days after application of treatments - DAT) Chlorophyll b level was highest in marandu-grass + sorghum and control (single marandu-grass and no nicosulfuron). At doses $15.0 \mathrm{~g} \mathrm{~L}^{-1}$ and $30.0 \mathrm{~g} \mathrm{~L}^{-1}$ chlorophyll $b$ contents were higher in the treatment of marandu-grass + sorghum. There was a trend of reduction in chlorophyll b concentrations with increasing doses of nicosulfuron for treatments of marandu-grass + eucalyptus $12 \times 2 \mathrm{~m}$ and single marandu-grass (Table 2 ). The increase of chlorophyll $b$ in leaves subjected to low luminosity is an important characteristic because chlorophyll b captures energy from other wavelengths and transfers it to the chlorophyll which effectively acts on the photochemical reactions of photosynthesis and represents a mechanism of adaptation to the condition of less luminous intensity (Scalon et al., 2003; Scalon et al., 2013). At 120 DAT, the level of chlorophyll $b$ was higher in the single marandu-grass treatment at zero nicosulfuron. At the doses of $15.0 \mathrm{~g} \mathrm{~L}^{-1}$ and $30.0 \mathrm{~g} \mathrm{~L}^{-1}$, the control and marandu + sorghum treatments had the highest values of chlorophyll $b$. Evaluation of doses of the herbicide within each treatment showed a reduction in chlorophyll $b$ value with increasing doses, except for the plots where the marandu-grass was cultivated together with the sorghum (Table 2).

\section{Chlorophyll a content in marandu-grass plants}

The chlorophyll a content at 30 DAT at the zero dose of the herbicide showed higher values of this variable in the cultivated marandu-grass. However, at doses $15.0 \mathrm{~g} \mathrm{~L}^{-1}$ and $30.0 \mathrm{~g} \mathrm{~L}^{-1}$, the highest value of chlorophyll a was observed in the marandu-grass + sorghum treatment. Chlorophyll a level was decreased with increase of nicosulfuron in all evaluated treatments (Table 3). At 120 DAT, the levels of chlorophyll a did not show differences between treatments at the zero dose of the herbicide. However, at the doses $15.0 \mathrm{~g} \mathrm{~L}^{-1}$ and $30.0 \mathrm{~g} \mathrm{~L}^{-1}$ the plots cultivated with marandu-grass + sorghum presented the highest values of chlorophyll a. The increase in the dose of nicosulfuron promoted a decrease in chlorophyll a levels in all treatments, except in the plots where the marandu-grass was cultivated with the sorghum (Table 3).

\section{Total chlorophyll contents of marandu-grass plants}

The total chlorophyll content at 30 DAT was lower in marandu-grass + eucalyptus integration at $12 \times 2 \mathrm{~m}$ and $12 \times 3$ $\mathrm{m}$ spacings at the zero doses of the herbicide. At the doses $15.0 \mathrm{~g} \mathrm{~L}^{-1}$ and $30.0 \mathrm{~g} \mathrm{~L}^{-1}$ the highest values of total chlorophyll were observed in the plots of marandu-grass integration with sorghum (Table 4). In the sorghum integration system, the marandu-grass cultivated in the culture line was in a shaded environment. Higher concentrations of chlorophyll in shaded plants are consistent with results presented by Mishara et al. (2010). Leaves of plants submitted to shading have higher concentration of chlorophyll than leaves of plants grown in full sun. However, if the content is expressed per unit area of leaf, the concentration is lower in the leaves of shade. Therefore, shaded leaves invest more energy in the production of photosynthetic pigments, allowing an optimization in the use of incident light intensity (Deng et al., 2012).

The chlorophyll content is related to the nitrogen content in plants, so the lower efficiency in nutritional use caused by factors such as competition, directly influence the chlorophyll synthesis (Teixeira Filho et al., 2009; Viana et al., 2010). The lower degradation of chlorophyll molecules by photo-oxidation in plants with restricted radiation, allows maintenance of higher levels of chlorophyll in leaves developed in the shade. In addition, the increase in chlorophyll content may be linked to the increased development of grana, a cluster of membranes (thylakoids), arranged in a pile, containing chlorophyll and located in chloroplasts (Lopes et al., 2017). Oliveira et al. (2013), grew Andropogon gayanus cv. Planaltina and Panicum maximum cv. Tanzânia under artificial shading in pots obtained higher levels of chlorophyll a in shaded plants of the two forage species, when compared to those maintained in full sun. Total chlorophyll content decreased with increasing nicosulfuron dose in all treatments (Table 4). The chlorophyll-meter measurements identify chlorophyll content in the plants. The values showed a positive correlation with the nitrogen content, since 50 to $70 \%$ of the total nitrogen of the leaves are constituents of compounds associated with chloroplasts and the content of chlorophyll in leaves (Cabral et al., 2016). According to Cabral et al. (2013), SPAD readings in marandu-grass less than 26 indicate nitrogen deficiency, which leads to chlorosis initially in older leaves and progresses to generalized yellowing. In the present work, the values of total chlorophyll were superior to $26 \mathrm{mg} \mathrm{m}^{-2}$ in all the plots.

The total chlorophyll content at 120 DAT, showed no difference between treatments at zero and $15.0 \mathrm{~g} \mathrm{~L}^{-1}$ of nicosulfuron doses. At the dose $30.0 \mathrm{~g} \mathrm{~L}^{-1}$, the treatment of marandu-grass + sorghum showed the highest values of total chlorophyll. The total chlorophyll contents were reduced with the herbicide dose increase in all treatments, except in 
Table 1. Soil chemical characteristics of the experimental area.

\begin{tabular}{lc}
\hline Characteristics & Value \\
\hline $\mathrm{pH}$ in $\mathrm{H}_{2} \mathrm{O}$ & 5.90 \\
$\mathrm{P}\left(\mathrm{mg} \mathrm{dm}^{-3}\right)$ & 1.03 \\
$\mathrm{~K}^{+}\left(\mathrm{mg} \mathrm{dm}^{-3}\right)$ & 146.33 \\
$\mathrm{Ca}^{2+}\left(\mathrm{cmol}_{\mathrm{c}} \mathrm{dm}^{-3}\right)$ & 4.75 \\
$\mathrm{Mg}^{2+}\left(\mathrm{cmol}_{\mathrm{c}} \mathrm{dm}^{-3}\right)$ & 0.76 \\
$\mathrm{Al}^{3+}\left(\mathrm{cmol}_{\mathrm{c}} \mathrm{dm}^{-3}\right)$ & 0.10 \\
$\mathrm{H}+\mathrm{Al}\left(\mathrm{cmol}_{\mathrm{c}} \mathrm{dm}^{-3}\right)$ & 4.23 \\
$\mathrm{SB}\left(\mathrm{cmol} \mathrm{cm}^{-3}\right)$ & 3.97 \\
$\mathrm{CEC}(\mathrm{t})\left(\mathrm{cmol}_{\mathrm{c}} \mathrm{dm}^{-3}\right)$ & 4.07 \\
$\mathrm{~V}(\%)$ & 47.66 \\
$\mathrm{~m}(\%)$ & 4.00 \\
$\mathrm{SOM}\left(\mathrm{g} \mathrm{dm}^{-3}\right)$ & 39.20 \\
$\mathrm{P}-\mathrm{rem}\left(\mathrm{mg} \mathrm{L}^{-1}\right)$ & 13.00 \\
$\mathrm{Zn}\left(\mathrm{mg} \mathrm{dm}^{-3}\right)$ & 0.67 \\
$\mathrm{Fe}\left(\mathrm{mg} \mathrm{dm}^{-3}\right)$ & 39.30 \\
$\mathrm{Mn}\left(\mathrm{mg} \mathrm{dm}^{-3}\right)$ & 59.56 \\
$\mathrm{Cu}\left(\mathrm{mg} \mathrm{dm}^{-3}\right)$ & 1.30 \\
$\left.\mathrm{~B}(\mathrm{mg} \mathrm{dm})^{-3}\right)$ & 0.10 \\
\hline
\end{tabular}

Table 2. Chlorophyll b content $\left(\mathrm{mg} \mathrm{m}^{-2}\right)$ in marandu-grass plants in the first season at 30 and at 120 days after application of treatment.

\begin{tabular}{|c|c|c|c|c|}
\hline \multirow[t]{4}{*}{ Doses (\%) } & \multicolumn{4}{|c|}{ Chlorophyll b contents at 30 DAT } \\
\hline & \multicolumn{4}{|c|}{ Treatments } \\
\hline & \multicolumn{2}{|c|}{ Consortium (Marandu-grass + Eucalyptus) } & \multirow[t]{2}{*}{ Marandu-grass single } & \multirow{2}{*}{$\begin{array}{c}\text { Marandu-grass + } \\
\text { Sorghum }\end{array}$} \\
\hline & $12 \times 2$ & $12 \times 3$ & & \\
\hline $0.0\left(0.0 \mathrm{~g} \mathrm{~L}^{-1}\right)$ & $8.25 \mathrm{~b} \mathrm{~A}$ & $7.67 \mathrm{~b} \mathrm{~A}$ & 10.77 a $A$ & 10.70 a $A$ \\
\hline $25.0\left(15.0 \mathrm{~g} \mathrm{~L}^{-1}\right)$ & $7.75 \mathrm{~b} \mathrm{~A}$ & $7.15 \mathrm{~b} \mathrm{~A}$ & 6.75 b B & 9.55 a $A$ \\
\hline $50.0\left(30.0 \mathrm{~g} \mathrm{~L}^{-1}\right)$ & $6.60 \mathrm{~b} \mathrm{~B}$ & $6.85 \mathrm{~b} \mathrm{~A}$ & $7.42 \mathrm{~b} \mathrm{~B}$ & 10.42 a A \\
\hline \multirow[t]{2}{*}{ VC (\%) } & 8.15 & & & \\
\hline & \multicolumn{4}{|c|}{ Chlorophyll b contents at 120 DAT } \\
\hline \multirow[t]{2}{*}{ Doses (\%) } & \multicolumn{2}{|c|}{ Consortium (Marandu-grass + Eucalyptus) } & \multirow[t]{2}{*}{ Marandu-grass single } & \multirow{2}{*}{$\begin{array}{c}\text { Marandu grass + } \\
\text { Sorghum }\end{array}$} \\
\hline & $12 \times 2$ & $12 \times 3$ & & \\
\hline $0.0\left(0.0 \mathrm{~g} \mathrm{~L}^{-1}\right)$ & $9.77 \mathrm{~b} \mathrm{~A}$ & $9.67 \mathrm{~b} \mathrm{~A}$ & 10.57 a $\mathrm{A}$ & $9.85 \mathrm{~b} \mathrm{~A}$ \\
\hline $25.0\left(15.0 \mathrm{~g} \mathrm{~L}^{-1}\right)$ & $8.77 \mathrm{~b} \mathrm{~B}$ & $9.00 \mathrm{~b} \mathrm{~B}$ & 9.85 a B & 9.85 a $\mathrm{A}$ \\
\hline $50.0\left(30.0 \mathrm{~g} \mathrm{~L}^{-1}\right)$ & $8.32 \mathrm{~b} \mathrm{~B}$ & $8.82 \mathrm{~b} \mathrm{~B}$ & 9.15 a B & 9.75 a $\mathrm{A}$ \\
\hline VC (\%) & \multicolumn{4}{|c|}{4.48} \\
\hline
\end{tabular}

Table 3. Chlorophyll a content $\left(\mathrm{mg} \mathrm{m}^{-2}\right)$ in marandu-grass plants in the first season at 30 and at 120 days after application of treatment.

\begin{tabular}{|c|c|c|c|c|}
\hline \multirow[t]{4}{*}{ Doses (\%) } & \multicolumn{4}{|c|}{ Chlorophyll a contents at 30 DAT } \\
\hline & \multicolumn{4}{|c|}{ Treatments } \\
\hline & \multicolumn{2}{|c|}{ Consortium (Marandu-grass + Eucalyptus) } & \multirow[t]{2}{*}{ Marandu-grass single } & \multirow{2}{*}{$\begin{array}{c}\text { Marandu-grass + } \\
\text { Sorghum }\end{array}$} \\
\hline & $12 \times 2$ & $12 \times 3$ & & \\
\hline $0.0\left(0.0 \mathrm{~g} \mathrm{~L}^{-1}\right)$ & $29.55 \mathrm{cb} \mathrm{A}$ & $28.07 \mathrm{cA}$ & 32.57 a A & $31.10 \mathrm{ab} A$ \\
\hline $25.0\left(15.0 \mathrm{~g} \mathrm{~L}^{-1}\right)$ & 27.75 b B & 26.70 b B & $26.80 \mathrm{~b} \mathrm{~B}$ & 30.20 a $A B$ \\
\hline $50.0\left(30.0 \mathrm{~g} \mathrm{~L}^{-1}\right)$ & $26.90 \mathrm{~b} \mathrm{~B}$ & 26.05 b B & $23.62 \mathrm{cC}$ & 28.32 a B \\
\hline \multirow[t]{2}{*}{$\mathrm{VC}(\%)$} & \multicolumn{4}{|c|}{3.27} \\
\hline & \multicolumn{4}{|c|}{ Chlorophyll a contents at 120 DAT } \\
\hline \multirow[t]{2}{*}{ Doses (\%) } & \multicolumn{2}{|c|}{ Consortium (Marandu-grass + Eucalyptus) } & \multirow[t]{2}{*}{ Marandu-grass single } & \multirow{2}{*}{$\begin{array}{c}\text { Marandu grass + } \\
\text { Sorghum }\end{array}$} \\
\hline & $12 \times 2$ & $12 \times 3$ & & \\
\hline $0.0\left(0.0 \mathrm{~g} \mathrm{~L}^{-1}\right)$ & 32.37 a $A$ & 32.15 a $A$ & 32.67 a $A$ & 32.20 a A \\
\hline $25.0\left(15.0 \mathrm{~g} \mathrm{~L}^{-1}\right)$ & 30.75 b B & 30.72 b B & $30.30 \mathrm{~b} \mathrm{~B}$ & 31.55 a $A$ \\
\hline $50.0\left(30.0 \mathrm{~g} \mathrm{~L}^{-1}\right)$ & 30.02 b B & 29.95 b B & 28.85 b B & 31.55 a A \\
\hline VC (\%) & \multicolumn{4}{|c|}{2.32} \\
\hline
\end{tabular}


Table 4. Total chlorophyll contents $\left(\mathrm{mg} \mathrm{m}^{-2}\right)$ of marandu-grass plants in the first season at 30 and at 120 days after application of treatment.

\begin{tabular}{|c|c|c|c|c|c|}
\hline \multirow{4}{*}{ Doses (\%) } & \multicolumn{5}{|c|}{ Total chlorophyll contents at 30 DAT } \\
\hline & \multicolumn{5}{|c|}{ Treatments } \\
\hline & \multicolumn{2}{|c|}{ Consortium (Marandu-grass + Eucalyptus) } & \multirow[t]{2}{*}{ Marandu-grass single } & \multirow{2}{*}{$\begin{array}{l}\text { Marandu-grass } \\
\text { Sorghum }\end{array}$} & \multirow[t]{2}{*}{+} \\
\hline & $12 \times 2$ & $12 \times 3$ & & & \\
\hline $0.0\left(0.0 \mathrm{~g} \mathrm{~L}^{-1}\right)$ & $37.80 \mathrm{~b} \mathrm{~A}$ & $35.57 \mathrm{~b} \mathrm{~A}$ & 40.40 a $\mathrm{A}$ & 41.04 a $A$ & \\
\hline $25.0\left(15.0 \mathrm{~g} \mathrm{~L}^{-1}\right)$ & $35.00 \mathrm{~b} \mathrm{AB}$ & $33.67 \mathrm{c} A B$ & $32.45 \mathrm{c} \mathrm{B}$ & 39.90 a A & \\
\hline $50.0\left(30.0 \mathrm{~g} \mathrm{~L}^{-1}\right)$ & 33.25 b B & 32.62 b B & $30.30 \mathrm{~b} \mathrm{~B}$ & 34.35 a B & \\
\hline \multirow[t]{2}{*}{ VC (\%) } & \multicolumn{5}{|c|}{3.72} \\
\hline & \multicolumn{5}{|c|}{ Total chlorophyll contents at 120 DAT } \\
\hline \multirow[t]{2}{*}{ Doses (\%) } & \multicolumn{2}{|c|}{ Consortium (Marandu-grass + Eucalyptus) } & \multirow[t]{2}{*}{ Marandu-grass single } & \multirow{2}{*}{$\begin{array}{l}\text { Marandu } \\
\text { Sorghum }\end{array}$} & + \\
\hline & $12 \times 2$ & $12 \times 3$ & & & \\
\hline $0.0\left(0.0 \mathrm{~g} \mathrm{~L}^{-1}\right)$ & 42.22 a $A$ & 41.82 a $\mathrm{A}$ & 42.35 a $\mathrm{A}$ & 41.35 a $\mathrm{A}$ & \\
\hline $25.0\left(15.0 \mathrm{~g} \mathrm{~L}^{-1}\right)$ & 39.55 a B & 39.67 a B & 39.45 a B & 40.72 a $A$ & \\
\hline $50.0\left(30.0 \mathrm{~g} \mathrm{~L}^{-1}\right)$ & 38.32 b B & $38.80 \mathrm{~b} \mathrm{~B}$ & $38.32 \mathrm{~b} \mathrm{~B}$ & 40.62 a A & \\
\hline
\end{tabular}

${ }^{*}$ Averages followed by the same lowercase letter in the line and capital letter in the column do not differ from each other by Tukey's test at $5 \%$ probability; VC = variation coeficient.

Table 5. Chlorophyll a/b ratio of marandu-grass plants in the first season at 30 and at 120 days after application of treatment.

\begin{tabular}{|c|c|c|c|c|}
\hline & \multicolumn{4}{|c|}{ Chlorophyll a/b ratio at 30 DAT } \\
\hline & \multicolumn{4}{|c|}{ Treatments } \\
\hline \multirow[t]{2}{*}{ Doses (\%) } & \multicolumn{2}{|c|}{ Consortium (Marandu-grass + Eucalyptus) } & \multirow[t]{2}{*}{ Marandu-grass single } & \multirow{2}{*}{$\begin{array}{l}\text { Marandu-grass + } \\
\text { Sorghum }\end{array}$} \\
\hline & $12 \times 2$ & $12 \times 3$ & & \\
\hline $0.0\left(0.0 \mathrm{~g} \mathrm{~L}^{-1}\right)$ & $2.95 \mathrm{cA}$ & $2.81 \mathrm{cA}$ & $3.87 \mathrm{~b} \mathrm{~A}$ & 6.22 a $A$ \\
\hline $25.0\left(15.0 \mathrm{~g} \mathrm{~L}^{-1}\right)$ & $2.70 \mathrm{~b} \mathrm{~A}$ & $2.64 \mathrm{~b} \mathrm{~A}$ & $2.99 \mathrm{~b} \mathrm{~B}$ & 4.06 a B \\
\hline $50.0\left(30.0 \mathrm{~g} \mathrm{~L}^{-1}\right)$ & $2.59 \mathrm{~b} \mathrm{~A}$ & $2.65 \mathrm{~b} \mathrm{~A}$ & 3.06 a B & 3.60 a B \\
\hline \multirow[t]{2}{*}{ VC (\%) } & \multicolumn{4}{|c|}{11.14} \\
\hline & \multicolumn{4}{|c|}{ Chlorophyll a/b ratio at 120 DAT } \\
\hline \multirow[t]{2}{*}{ Doses (\%) } & \multicolumn{2}{|c|}{ Consortium (Marandu-grass + Eucalyptus) } & \multirow[t]{2}{*}{ Marandu-grass single } & \multirow{2}{*}{$\begin{array}{c}\text { Marandu grass + } \\
\text { Sorghum }\end{array}$} \\
\hline & $12 \times 2$ & $12 \times 3$ & & \\
\hline $0.0\left(0.0 \mathrm{~g} \mathrm{~L}^{-1}\right)$ & $3.31 \mathrm{~b} \mathrm{~A}$ & $3.35 \mathrm{~b} \mathrm{~A}$ & 4.20 a $\mathrm{A}$ & 4.13 a $\mathrm{A}$ \\
\hline $25.0\left(15.0 \mathrm{~g} \mathrm{~L}^{-1}\right)$ & 3.50 a A & 3.44 a A & 3.91 a A & 4.05 a $A$ \\
\hline $50.0\left(30.0 \mathrm{~g} \mathrm{~L}^{-1}\right)$ & 3.62 a $A$ & 3.42 a A & 4.13 a $\mathrm{A}$ & 4.08 a $\mathrm{A}$ \\
\hline
\end{tabular}

* Averages followed by the same lowercase letter in the line and capital letter in the column do not differ from each other by Tukey's test at $5 \%$ probability; VC = variation coeficient.

Table 6. Growth rate of the crop $\left(\mathrm{g} \mathrm{day}^{-1}\right)$ of marandu-grass plants at 120 days after application of treatment.

\begin{tabular}{|c|c|c|c|c|}
\hline \multirow{3}{*}{ Doses (\%) } & \multicolumn{4}{|c|}{ Treatments } \\
\hline & \multicolumn{2}{|c|}{ Consortium (Marandu-grass + Eucalyptus) } & \multirow[t]{2}{*}{ Marandu-grass single } & \multirow{2}{*}{$\begin{array}{c}\text { Marandu-grass + } \\
\text { Sorghum }\end{array}$} \\
\hline & $12 \times 2$ & $12 \times 3$ & & \\
\hline $0.0\left(0.0 \mathrm{~g} \mathrm{~L}^{-1}\right)$ & $16.36 \mathrm{~b} \mathrm{~A}$ & $17.02 \mathrm{ab} A$ & 21.23 a $\mathrm{A}$ & $17.04 \mathrm{ab} A$ \\
\hline $25.0\left(15.0 \mathrm{~g} \mathrm{~L}^{-1}\right)$ & 15.66 a $A$ & 15.81 a $A$ & 16.22 a B & 16.46 a $\mathrm{A}$ \\
\hline $50.0\left(30.0 \mathrm{~g} \mathrm{~L}^{-1}\right)$ & 14.73 a $A$ & 15.69 a $A$ & $15.87 \mathrm{aB}$ & 15.76 a $A$ \\
\hline
\end{tabular}

*Averages followed by the same lowercase letter in the line and capital letter in the column do not differ from each other by Tukey's test at $5 \%$ probability; VC = variation coeficient.

the plots where the marandu-grass was cultivated in integration with the sorghum (Table 4).

Barbosa et al. (2018) verified that the application of glyphosate subdoses modifies the chlorophyll levels of the soybean genotypes, with a different response among them. According to the same authors, the higher subdoses increased the pigment content of the soybean leaves.

In a study of herbicide rates on African mahogany and Australian redcedar tree species, Brighenti and Muller (2014) found that chlorimuron at a dose of $7.5 \mathrm{~g} \mathrm{ha}^{-1}$ resulted in a reduction in chlorophyll content compared to the control for both tested cultures. Similarly, nicosulfuron reduced the chlorophyll content of African mahogany at a dose of $40.0 \mathrm{~g}$ $\mathrm{ha}^{-1}$.
Zera et al. (2011), worked on tolerance of different cultivars of sugarcane to herbicides and found that at 15 DAA the total chlorophyll content of all cultivars was reduced by clomazone, which caused white spots on the leaves.

The reduction of leaf chlorophyll values is indicative of biotic or abiotic stresses that modify the $\mathrm{CO}_{2}$ assimilation power, with physiological changes in photosynthetic activity (Baker; Rosenqvist, 2004). When two or more plants coexist in the same environment, some stressful relationships are established, such as the competition for essential resources for plant development (Zimdahl, 2004). 


\section{Chlorophyll $a / b$ ratio in marandu-grass plants}

The chlorophyll $\mathrm{a} / \mathrm{b}$ ratio at 30 DAT was higher in plots where marandu-grass was cultivated in a consortium with sorghum at zero dose (Table 5). Increasing the proportion of chlorophyll $b$ in shaded plants can be considered as an important characteristic in plant's adaptability to the shaded environments, since chlorophyll $b$ absorbs energy at wavelengths different from chlorophyll a and transfers the reaction center, the energy capture that effectively acts on the photochemical reactions (Scalon et al., 2013).

At the dose $15.0 \mathrm{~g} \mathrm{~L}^{-1}$ of the herbicide and at the dose $30.0 \mathrm{~g}$ $\mathrm{L}^{-1}$, the single marandu-grass and marandu-grass + sorghum treatments presented higher chlorophyll $\mathrm{a} / \mathrm{b}$. In treatments integrating marandu-grass + eucalyptus at $12 \times 2 \mathrm{~m}$ and $12 \times 3$ $\mathrm{m}$ spacings, no difference was observed in the chlorophyll $a / b$ ratio. However, when marandu grass was cultivated alone and together with sorghum the values of chlorophyll $a / b$ were increased (Table 5).

The chlorophyll $\mathrm{a} / \mathrm{b}$ ratio at 120 DAT was higher in treatments of single marandu-grass and marandu-grass + sorghum at zero dose of nicosulfuron (Table 5). He et al. (1996) observed that higher chlorophyll content in leaves of shaded tree species and chlorophyll $\mathrm{a} / \mathrm{b}$ ratio were higher in leaves of the same species that received higher sunshine. At doses $15.0 \mathrm{~g} \mathrm{~L}^{-1}$ and $30.0 \mathrm{~g} \mathrm{~L}^{-1}$, no differences were observed between treatments. Increased herbicide doses did not interfere with the chlorophyll $a / b$ ratio in all evaluated treatments (Table 5).

\section{Growth rate of marandu-grass plants}

Forage growth in association with tree species may be impaired or favored, depending on factors such as shade tolerance, tree shading, and competition between plants in relation to water and soil nutrients (Gómez et al., 2013). In addition, shade-tolerant forages exhibit morphophysiological changes when cultivated in the shade, which give them greater production capacity, compared to non-tolerant species under reduced light (Veras et al., 2010; Abraham et al., 2014).

The growth rate of the evaluated crop at the end of the cycle was higher in the marandu-grass cultivated alone at the zero dose of the product, when compared to the treatments in which the forage grew in integration systems (marandugrass + eucalyptus $12 \times 2 \mathrm{~m}, 12 \times 3 \mathrm{~m}$ and marandu-grass + sorghum). In the other doses, no difference was observed between treatments (Table 6). Daniel et al. (2004) evaluating the influence of the spacing between the eucalyptus in consortium with corn and observed that corn productivity was negatively affected in the smaller eucalyptus spacings and in the lines close to the trees, evidencing the influence of broader arrangements in favor of the increase in corn fodder production.

The productivity and persistence of forage grown under trees can be directly influenced by the effect of shading, which may interfere with the growth and development of the shoot and especially roots, decreasing both when the radiation levels are inadequate, reflexing reduction of the photosynthetic rate and the absorption of nutrients (Guenni et al., 2008). This explains the lower rate of forage crop growth in the growing environments under integration.

The increase of the herbicide dose caused reduction in growth rate of the crop only in the single marandu-grass treatment (Table 6).

\section{Materials and methods}

\section{Location and characterization of the study area}

The experiment was carried out at the Fazenda Experimental do Moura (FEM), belonging to the Universidade Federal dos Vales do Jequitinhonha e Mucuri (UFVJM). The FEM is located in the municipality of Curvelo-MG at coordinates $18^{\circ} 44^{\prime} 52.03^{\prime \prime} \mathrm{S}$ and $44^{\circ} 26^{\prime} 53.56^{\prime \prime} \mathrm{W}$. The experimental area was formed two years with eucalyptus, maize and Urochloa brizantha cv. Marandu (marandu-grass) in an agroforestry system. After the maize harvest, the area was maintained and managed without the presence of animals.

The soil of the experimental area was classified as Oxisol, with a clayey texture (Table 1 ).

\section{Treatments and experimental design}

The experiment was arranged in a randomized block design in a $4 \times 3$ factorial scheme with four replications. The first factor was composed of eucalyptus consortium in $12 \times 2$ and $12 \times 3 \mathrm{~m}$ spacings, intercropped with forage Urochloa brizantha cv. Marandu (marandu-grass), in crop-forestrylivestock systems, and the sorghum + marandu-grass and marandu-grass in monoculture. The second factor was constituted by doses 0,15 and $30 \mathrm{~g} \mathrm{ha}^{-1}$ of nicosulfuron applied in the marandu-grass two days before sowing of sorghum, equivalent to 0,25 and $50 \%$ of the commercial dose recommended, respectively.

Therefore, 12 treatments were used, namely: marandu-grass consortium with eucalyptus in the $12 \times 2 \mathrm{~m}$ spacing, with application of $0.0 \mathrm{~g} \mathrm{~L}^{-1}$ of nicosulfuron (T1); consortium of marandu-grass with eucalyptus in the $12 \times 2 \mathrm{~m}$ spacing, with application of $25.0 \mathrm{~g} \mathrm{~L}^{-1}$ of nicosulfuron (T2); consortium of marandu-grass with eucalyptus in the $12 \times 2 \mathrm{~m}$ spacing, with application of $50.0 \mathrm{~g} \mathrm{~L}^{-1}$ of nicosulfuron (T3); consortium of marandu-grass with eucalyptus in the $12 \times 3 \mathrm{~m}$ spacing, with application of $0.0 \mathrm{~g} \mathrm{~L}^{-1}$ of nicosulfuron (T4); consortium of marandu-grass with eucalyptus in the $12 \times 3 \mathrm{~m}$ spacing, with application of $25.0 \mathrm{~g} \mathrm{~L}^{-1}$ of nicosulfuron (T5); consortium of marandu-grass with eucalyptus in the $12 \times 3 \mathrm{~m}$ spacing, with application of $50.0 \mathrm{~g} \mathrm{~L}^{-1}$ of nicosulfuron (T6); sorghum consortium with marandu-grass with application of $0.0 \mathrm{~g} \mathrm{~L}^{-1}$ of nicosulfuron (T7); sorghum consortium with marandugrass with application of $25.0 \mathrm{~g} \mathrm{~L}^{-1}$ of nicosulfuron (T8); sorghum consortium with marandu-grass with application of $50.0 \mathrm{~g} \mathrm{~L}^{-1}$ of nicosulfuron (T9); monoculture of marandugrass with application of $0.0 \mathrm{~g} \mathrm{~L}^{-1}$ of nicosulfuron (T10); monoculture of marandu-grass with application of $25.0 \mathrm{~g} \mathrm{~L}^{-1}$ of nicosulfuron (T11); and monoculture of marandu-grass with application of $50.0 \mathrm{~g} \mathrm{~L}^{-1}$ of nicosulfuron (T12).

The experimental units of the treatments in crop-forestrylivestock systems had the following dimensions: $36 \mathrm{~m}$ wide by $18 \mathrm{~m}$ long, with a total area of $648 \mathrm{~m}^{2}$, composed of four single rows of eucalyptus spaced every $12 \mathrm{~m}$, interspersed with sorghum in a consortium with marandu-grass. The subplots had dimensions of $12 \mathrm{~m}$ wide by $18 \mathrm{~m}$ long, totally $216 \mathrm{~m}^{2}$. For the monoculture plots of marandu-grass and sorghum + marandu-grass, the dimensions were $10 \mathrm{~m}$ wide by $36 \mathrm{~m}$ long, totally $360 \mathrm{~m}^{2}$, and the subplots $10 \mathrm{~m}$ wide by $12 \mathrm{~m}$ long, totally $120 \mathrm{~m}^{2}$. 


\section{Agronomic practices}

The sowing of sorghum was carried out in December 2016, regulating the machinery with spacing of $0.9 \mathrm{~m}$ between sorghum lines and ten seeds per linear meter, in order to reach 111,115 plants of sorghum $\mathrm{ha}^{-1}$. The sowing fertilization was $400 \mathrm{~kg} \mathrm{ha}^{-1}$ of the formulation $\mathrm{N}-\mathrm{P}_{2} \mathrm{O}_{5}-\mathrm{K}_{2} \mathrm{O}$ (4-30-16). In the plot of sorghum + marandu-grass, sowing and fertilization was completed in the same time in the cropagroforestry-livestock system. Top-dressing fertilization of sorghum + marandu-grass and marandu-grass in monoculture and crop-agroforestry-livestock system was performed when the sorghum presented four completely expanded leaves using $100 \mathrm{~kg}$ of $\mathrm{N} \mathrm{ha}^{-1}, 50 \%$ with urea and $50 \%$ with ammonium sulfate. In the control of Spodoptera frugiperda (fall armyworm), $0.5 \mathrm{~kg} \mathrm{ha}^{-1}$ of the active principle deltamethrin (Decis ${ }^{\circledast}$ ) was used in the sorghum crop. The insecticide was sprayed with a flat spray nozzle XR 11002 at a constant pressure of $210 \mathrm{kPa}$, applying a volume of syrup equivalent to $200 \mathrm{~L} \mathrm{ha}{ }^{-1}$. The herbicide nicosulfuron was applied in the marandu-grass, two days before sowing (DBS) of the sorghum. For this purpose, we used a costal constant pressure sprayer, equipped with XR11002 tip, providing a spray volume of $200 \mathrm{~L} \mathrm{ha}^{-1}$. The application was performed at the end of the afternoon, under conditions of lower temperature and low wind speed.

\section{Traits measured}

The experiment was conducted from December 2016 to April 2017. During the experimental period, the shading rates in the understory, light quality, physiological and productive characteristics of marandu-grass and sorghum were measured.

The chlorophyll a $\left(\mathrm{mg} \mathrm{m}^{-2}\right)$ and chlorophyll b $\left(\mathrm{mg} \mathrm{m}^{-2}\right)$ were measured at 30 and 120 days after the application of nicosulfuron using a portable chlorophyll meter, six measurements per plant (six leaves adults). The total chlorophyll content (chlorophyll a + chlorophyll b $-\mathrm{mg} \mathrm{m}^{-2}$ ) and chlorophyll $\mathrm{a} / \mathrm{b}$ ratio (chlorophyll a / chlorophyll b) were calculated.

Forage plants were sampled using two $1 \mathrm{~m}^{2}$ frames per plot at 120 days after emergence of the marandu-grass ( 120 days after the application of nicosulfuron). The samples were transferred to the Laboratório de Forragicultura do Departamento de Zootecnia da UFVJM and dried in a greenhouse until constant mass, being weighed in a precision scale. Shoot mass was used to calculate the growth rate $\left(\mathrm{g} \mathrm{day}^{-1}\right)$ of the crop (shoot dry matter mass / number of days from emergence to harvest).

\section{Statistical anlysis}

Light, productivity and plant physiology data were submitted to analysis of variance (ANOVA) at $5 \%$ of significance. The averages were compared by Tukey's test at $5 \%$ significance. All statistical analyzes were performed in software R (2008).

\section{Conclusion}

The content of chlorophyll a, chlorophyll b and total of marandu-grass were reduced under nicosulfuron subdoses, except for the treatment of marandu+sorghum. The marandu-grass growth was negatively affected by integration with eucalyptus with greater density in the treatment without application of nicousulfuron.

Subdoses of nicosulfuron do not affect the growth of marandu-grass in a consortium with eucalyptus or sorghum.

\section{Acknowledgement}

This study was financed in part by the Coordenação de Aperfeiçoamento de Pessoal de Nível Superior - Brasil (CAPES)- Finance Code 001 and Grant number 88881.068513/2014-01. We thank to Pró-Reitoria de Pesquisa (PRPq) of Universidade Federal de Minas Gerais (UFMG) for providing language help.

\section{References}

Abraham EM, Kyriazopoulos AP, Parissi ZM, Kostopoulou M, Anjalanidou K, Katsouta C (2014) Growth, dry matter production, phenotypic plasticity, and nutritive value of three natural populations of Dactylis glomerata L. under various shading treatments. Agrofor Syst. 88: 287-299.

Baker NR, Rosenqvist E (2004) Applications of chlorophyll fluorescence can improve crop production strategies: an examination of future possibilities. J Exp Bot. 55: 16071621.

Barbosa AP, Freiria GH, Gomes GR, Bertoncelli DJ, Bazzo JHB, Almeida LHC, Alves LAR (2018) Subdoses de glyphosate no desempenho fitométrico e bioquímico de soja convencional e transgênica. Sci Agric. 19: 36-42.

Brighenti AM, Muller MD (2014) Tolerância de plantas de Khaya ivorensis e Toona ciliata a herbicidas. Rev Floresta. 44: 747-754.

Cabral CEA, Abreu JG, Bonfim-Silva EM, Cabral CHA, Scaramuzza JF, Silva TJA (2013) Eficiência de produção e concentração de nitrogênio nos capins marandu, decumbens e convert submetidos à adubação nitrogenada. Biosci J. 29: 1653-1663.

Cabral CEA, Cabral LS, Bonfim-Silva EM, Carvalho KS, Kroth BE, Cabral CHA (2016) Resposta da Brachiaria brizantha cv. Marandu a fertilizantes nitrogenados associados ao fosfato natural reativo. Com Sci. 7: 66-72.

Chappelle EW, Kim MS, McMurtrey JE (1992) Ratio analysis of reflectance spectra (RARS): An algorithm for the remote estimation of the concentrations of chlorophyll $A$, chlorophyll B, and carotenoids in soybean leaves. Remote Sens Environ. 39: 239-247.

Concenço G, Ferreira EA, Ferreira FA, Santos JB (2007) Plasmodesmos: transporte simplástico de herbicidas na planta. Planta Daninha. 25: 423-432.

Daniel O, Bittecourt D, Gelain E (2004) Avaliação de um sistema agroflorestal eucalipto-milho no Mato Grosso do Sul. Agrossilvicultura. 1: 15-28.

De Lafontaine Y, Beauvais C, Cessna AJ, Gagnon P, Hudon C, Poissant $L$ (2014) Sulfonylurea herbicides in an agricultural catchment basin and its adjacent wetland in the St. Lawrence River basin. Sci Total Environ. 479-480: 1-10.

Deng Y, Shao Q, LI C, Ye X, Tang R (2012) Differential responses of double petal and multi petal jasmine to shading: II. Morphology, anatomy and physiology. Sci Hortic. 144: 19-28.

Gómez S, Guenni O, Bravo DE Guenni L (2013) Growth, leaf photosynthesis and canopy light use efficiency under differing irradiance and soil $\mathrm{N}$ supplies in the forage grass Brachiaria decumbens Stapf. Grass Forage Sci. 68: 395-407. 
Gómez S, Guenni O, Guenni LB (2012) Growth, leaf photosynthesis and canopy light use efficiency under differing irradiance and soil $\mathrm{N}$ supplies in the forage grass Brachiaria decumbens Stapf. Grass Forage Sci. 68: 395-407.

Guenni O, Seiter S, Figueroa R (2008) Growth responses of three Brachiaria species to light intensity and nitrogen supply. Trop Grassl. 42: 75-87.

He J, Chee CW, Goh CJ (1996) Photoinhibition of Heliconia under natural tropical conditions: the importance of leaf orientation for light interception and leaf temperature. Plant Cell Environ. 19: 1238-1248.

Lopes CM, Paciullo DSC, Araújo SAC, Gomide CAM, Morenz MJF, Villela SDJ (2017) Massa de forragem, composição morfológica e valor nutritivo de capim-braquiária submetido a níveis de sombreamento e fertilização. Arq Bras Med Vet Zoo.69: 225-233.

Mishra AK, Tiwari HS, Bhatt RK (2010) Growth, biomass production and photosynthesis of Cenchrus ciliaris L. under Acacia tortilis (Forssk.) Hayne based silvopastoral systems in semi-arid tropics. J Environ Biol. 31: 987- 993.

Oliveira CC, Villela SDJ, Almeida RG, Alves FV, Behling-Neto A, Martins PGMA (2014) Performance of Nellore heifers, forage mass, and structural and nutritional characteristics of Brachiaria brizantha grass in integrated production systems. Trop Anim Health Pro. 46: 167-172.

Oliveira FLR, Mota VA, Ramos MS, Santos LDT, Oliveira NJF, Geraseev LC (2013) Comportamento de Andropogon gayanus cv. 'planaltina' e Panicum maximum cv. 'tanzânia' sob sombreamento. Cienc Rural. 43: 348-354.

Santos DC, Guimarães Júnior R, Vilela L, Maciel GA, França AFS (2018) Implementation of silvopastoral systems in Brazil with Eucalyptus urograndis and Brachiaria brizantha: Productivity of forage and an exploratory test of the animal response. Agric Ecosyst Environ. 266: 174-180.
Scalon SPQ, Mota LHS, Mussury RM (2013) Osmotic conditioning and shading on the germination and on the initial growth of Myracrodruon urundeuva Allemão seedlings. An Acad Bras Ciênc. 85: 799-812.

Scalon SPQ; Mussury RM, Rigoni MR, Scalon Filho H (2003) Crescimento inicial de mudas de Bombacopsis glabra (Pasq.) A. Robyns sob condição de sombreamento. Rev Árvore. 27: 753-758.

Teixeira Filho MCM, Buzetti S, Andreotti M, Sá ME, Arf O, Megda MM (2009) Response of Irrigated Wheat Cultivars to Different Nitrogen Rates and Sources. Rev Bra Ciên Solo. 33: $1303-1310$

Valladares F, Niinemets Ü (2008) Shade tolerance, a key plant feature of complex nature and consequences. Annu Rev Ecol Evol Syst. 39: 237-257.

Veras VS, Oliveira ME, Lacerda MSB, Carvalho TB, Alves AA (2010) Produção de biomassa e estrutura do pasto de capim-andropogon em sistema silvipastoril e monocultura. Arq Bras Med Vet Zoo. 62: 200-207.

Viana, EM, Kiehl JC (2010) Doses de nitrogênio e potássio no crescimento do trigo. Bragantia. 69: 975-982.

Wang W, Zhu J, Tang G, Huo H, Zhang W, Liang Y, Dong H, Yang J, Cao Y (2019) Novel herbicide ionic liquids based on nicosulfuron with increased efficacy. New J Chem. 43: 827833.

Zera FS, Azania CAM, Schiavetto AR, Lorenzato CM, Azania AAPM (2011) Tolerância de diferentes cultivares de cana de-açúcar (Saccharum spp.) a herbicidas. Planta Daninha. 29: 591-599.

Zimdahl RL (2004) Weed-Crop competition - A Review, 2a edn. Blackwell Publishing, IOWA. 